Journal of Applied Pharmaceutical Science Vol. 5 (10), pp. 147-150, October, 2015

Available online at http://www.japsonline.com

DOI: 10.7324/JAPS.2015.501025

ISSN 2231-3354 (cc) BY-NC-SA

\title{
Antibacterial and antioxidant activities of methanolic leaf extract of Maerua crassifolia
}

\author{
Kingsley Chimsorom Ckilaka ${ }^{*}$, Godwin Christian Akuodor ${ }^{2}$, Joseph Linus Akpan², Emeka Daniel Ogiji², \\ Chukwuemeka Okorie Eze ${ }^{3}$, Basil Chukwuma Ezeokpo ${ }^{3}$ \\ ${ }^{1}$ Department of Pharmacology and Therapeutics, College of Health Sciences, Nnamdi Azikiwe University, Awka, Nigeria. \\ ${ }^{2}$ Department of Pharmacology and Therapeutics, Faculty of Medicine, Ebonyi State University, Abakaliki, Nigeria. \\ ${ }^{3}$ Department of Internal Medicine, Faculty of Medicine, Ebonyi State University, Abakaliki, Nigeria.
}

\author{
ARTICLE INFO \\ Article history: \\ Received on: 26/07/2015 \\ Revised on: 25/08/2015 \\ Accepted on: 14/09/2015 \\ Available online: 28/10/2015 \\ Key words: \\ Maerua crassifolia, leaf \\ extract, methanol, \\ antibacterial agent, \\ DPPH, antioxidant.
}

\begin{abstract}
The objective of this study was to investigate the antibacterial and antioxidant activities of the methanol leaf extract of Maerua crassifolia, an important medicinal plant used in Nigeria. The antibacterial properties of the methanol extract were studied against clinically important bacteria viz; Staphylococcus aureus, Shigella spp., Salmonella typhi, Bacillus subtilis and Escherichia coli by disc diffusion method. The free radical scavenging potential of the extract was assessed by measuring its capability for scavenging 2, 2-diphenyl-1-picrylhydrazyl (DPPH) radical. The methanol leaf extract of Maerua crassifolia at the concentration of $12.5-150 \mu \mathrm{g} / \mathrm{ml}$, showed significant activity against all the tested organisms. The observed antioxidant activity of the leaf extract suggests that the extract is a potential source of natural antioxidant and could be useful in the treatment of diseases.
\end{abstract}

\section{INTRODUCTION}

The use of medicinal plants as traditional health remedies is the most popular for over $80 \%$ of the world population, and it has been reported to possess minimal side effect (Kumar et al., 2012). The importance of medicinal plants remains even of greater relevance with the global shift to obtain drugs from plants sources, and as a result of which attention has been given to the medicinal value of herbal remedies for safety and efficacy (Abubakar et al., 2009). These plants are used in herbal medicine in different countries, and are a source of numerous potent and effective drugs (Mahesh and Satish, 2008). There is an urgent need to investigate the medicinal plants used in traditional medicine with the aim of establishing their potential antimicrobial and antioxidant activities, and identifying the constituents responsible for these properties (Akuodor et al., 2013; Gupta and Mazumder, 2007; Lata and Ahuja, 2003).

* Corresponding Author

Chilaka KC, Department of Pharmacology and Therapeutics,

College of Health Sciences, Nnamdi Azikiwe University, Awka Nigeria.

E-mail: kingsleychilaka@yahoo.com
Maerua crassifolia which belong to the family Capparaceae is mainly found in the Saharan Africa. In Nigeria, the plant is mainly found in Sokoto and some parts of Zamfara and Katsina States. The leaf of this plant has long being used for the treatment of malaria (Akuodor et al., 2014), gastric acid, tooth ache and intestinal diseases (Rahman et al., 2004; Idris-Usman et al., 2010). However, there has not been any scientific information on antioxidant and antimicrobial activity of Maerua crassifolia leaf extract on some clinical isolates that can help ascertain some folkloric claims. This study is therefore, aimed at examining the antibacterial and antioxidant potentials of Maerua crassifolia leaf extract.

\section{MATERIALS AND METHODS}

\section{Plant Collection and identification}

The leaves of M. crassifolia were collected in March 2009 and were identified by Dr. (Mrs) Jemilat A. Ibrahim of the herbarium unit, National Institute for Pharmaceutical Research and Development (NIPRD), Abuja with voucher specimen number NIPRD/H/6406 for future reference. The international plant number index of M. crassifolia is Fl. Aegypt.-Arab. P. Cxiii. 1775. 


\section{Plant extraction}

$500 \mathrm{~g}$ of pulverized coarse powdered leaves was macerated overnight in methanol $(1.5 \mathrm{~L})$. The mixture was filtered and dried on a water bath at reduced temperature, and was stored in refrigerator for subsequent use.

\section{Phytochemical screening}

The methanol leaf extract was tested to determine the secondary constituents using standard procedures (Mukherjee, 2006; Parekh et al., 2006).

\section{Test organisms: Disc diffusion test}

The antibacterial activity was carried out by disc diffusion method as described by Mbaveng et al. (2008) with slight modifications. Fresh inoculum was prepared by suspending the colonies in physiological saline water ( $0.9 \%$ Normal saline). Using McFarland turbidity standards (0.5), the bacteria suspension were adjusted to $1 \times 10^{6} \mathrm{CFU} / \mathrm{ml}$ and were aseptically inoculated by swapping the surfaces of the Muller-Hinton agar plates. Whatman (No. 1) filter paper discs of $6 \mathrm{~mm}$ in diameter were made by punching the paper, and the blank discs were sterilized in the hot air oven at $120{ }^{\circ} \mathrm{C}$ for $90 \mathrm{~min}$. The discs were however saturated with $12.5,25,50,100$ and $150 \mu \mathrm{g} / \mathrm{ml}$ of the extract solution. With the aid of a sterile forceps, the dry impregnated discs were carefully placed on the agar plates. The positive and negative control were incorporated in each plate and incubated at $4{ }^{\circ} \mathrm{C}$ for $2 \mathrm{~h}$ for the extract to diffuse into the media. The experiments were carried out in duplicate. Thereafter, they were incubated at $37{ }^{\circ} \mathrm{C}$ for $24 \mathrm{~h}$. Antimicrobial activity of the extract was determined by measuring the size of the inhibition zone in $\mathrm{mm}$.

The Minimum Inhibitory Concentration (MIC) and Minimum Bactericidal Concentration (MBC) were determined (Mothana et al., 2008).

\section{Determination of the Minimum Inhibitory Concentration}

The method as described by Andrew (2001) was adopted to determine the Minimum Inhibitory Concentration (MIC). Six tubes were properly arranged in a rack and $0.5 \mathrm{ml}$ of nutrient broth was put into each test tube. The extract $(6.25,12.5,25,50,100$ and $125 \mu \mathrm{g} \mathrm{ml}$ ) were differently prepared. $0.5 \mathrm{ml}$ of the test organism was transferred into each of the test tube and incubated at $37^{\circ} \mathrm{C}$ for $24 \mathrm{~h}$. The MIC was considered as the least concentration of the extract which completely inhibited the growth of the test organism.

\section{Minimum Bactericidal Concentration (MIC and MBC)}

The Minimum Bactericidal Concentration was carried out following National Committee for Clinical Laboratory Standard (1993) method. A loopful of the broth taken from the MIC tubes without growth and streaked on a nutrient agar. The plates were incubated at $37{ }^{\circ} \mathrm{C}$ for $24 \mathrm{~h}$. The lowest concentration of the methanol leaf extract without visible growth after incubation was considered as Minimum Bactericidal Concentration.
Antioxidant activity: 2, 2 diphenyl-1-picrylhydyrayl (DPPH) radical scavenging activity

DPPH scavenging activity of the extract was measured by the spectrophotometeric method of Aweh et al., (2010) with slight modifications. To a methanol solution of DPPH, $0.05 \mathrm{ml}$ of the extract dissolved in ethanol was added at different concentrations $(100-500 \mu \mathrm{g} / \mathrm{ml})$ Control was prepared as above but without the sample extract and methanol was used for the baseline correction. The changes in the absorbance of the plant sample were measured at $517 \mathrm{~nm}$ and the percentage inhibition calculated by using the formula:

$$
\% \text { inhibition }=\frac{\text { Control }- \text { Test } \times 100}{\text { Control }}
$$

\section{Statistical analysis}

The mean of the reading measured for each zone in the sensitivity assay was taken as the zone of inhibition of the clinical isolates. One way ANOVA was used to compare mean and the differences were considered significant at $\mathrm{P}<0.05$.

\section{RESULTS AND DISCUSSION}

\section{Phytochemical studies}

Phytochemical screening of methanol leaf extract of Maerua crassifolia revealed the presence of alkaloids, saponins, tannins, terpenoids, flavonoids, steroids phenol and cardiac glycosides. However, phlobatannins and anthraquinones were absent. These secondary metabolites have been reported to possess different biological activities (Panda and Kar, 2007).

Table 1: Antibacterial effect of the methanol leaf extract of $M$. crassifolia

\begin{tabular}{llcccc}
\hline Organisms & \multicolumn{5}{c}{ Extract $(\boldsymbol{\mu g} / \mathbf{m l})$ zone of inhibition $(\mathbf{m m})}$. \\
\hline & $\mathbf{1 2 . 5}$ & $\mathbf{2 5}$ & $\mathbf{5 0}$ & $\mathbf{1 0 0}$ & $\mathbf{1 5 0}$ \\
\hline S. aureus & $12.00 \pm 2.00$ & $14.33 \pm 1.20$ & $15.67 \pm 2.10$ & $20.75 \pm 2.15$ & $29.60 \pm 0.00$ \\
S. typhi & $10.67 \pm 0.81$ & $13.00 \pm 1.64$ & $16.33 \pm 1.35$ & $19.00 \pm 2.00$ & $24.10 \pm 1.67$ \\
B. subtilis & $9.33 \pm 1.04$ & $12.00 \pm 2.11$ & $14.55 \pm 2.11$ & $18.67 \pm 1.33$ & $22.00 \pm 1.11$ \\
Shigella & $14.60 \pm 2.10$ & $16.30 \pm 2.04$ & $20.49 \pm 2.70$ & $22.80 \pm 3.40$ & $27.50 \pm 2.05$ \\
spp. & & & & & \\
E.coli & $7.79 \pm 3.00$ & $10.00 \pm 2.30$ & $12.00 \pm 2.00$ & $16.70 \pm 1.40$ & $20.30 \pm 1.45$ \\
\hline \multicolumn{7}{l}{ Values are expressed as mean \pm S.E.M } & & &
\end{tabular}

Table 2: Antibacterial effects (MIC/MBC in $\mu \mathrm{g} / \mathrm{ml}$ ) of the methanolic leaf extract of $M$. crassifolia

\begin{tabular}{lcc}
\hline Test organism & \multicolumn{2}{c}{ Methanolic leaf extract } \\
& MIC & MBC \\
\hline S.aurues & 10 & 20 \\
S. typhi & 7 & 14 \\
B.subtilis & 9 & 18 \\
Shigella spp & 9 & 18 \\
E. coli & 12 & 24 \\
\hline
\end{tabular}

Table 3: DPPH scavenging effect of methanol root extract of $M$. crassifolia at different concentrations $(\mu \mathrm{g} / \mathrm{ml})$ and $\mathrm{IC}_{50}$ values.

\begin{tabular}{ccc}
\hline Conc. $\boldsymbol{\mu g} / \mathbf{m l}$ & MEMC & Standard (Ascorbic acid) \\
\hline 100 & $58.7 \pm 2.3$ & $92.4 \pm 2.2$ \\
200 & $67.8 \pm 3.6$ & $94.3 \pm 1.5$ \\
300 & $78.5 \pm 2.7$ & $95.5 \pm 1.3$ \\
400 & $86.9 \pm 2.5$ & $96.3 \pm 0.7$ \\
500 & $91.2 \pm 1.5$ & $96.2 \pm 0.9$ \\
IC $_{50}$ & $58.9 \pm 3.7$ & $4.8 \pm 0.9$
\end{tabular}

Results are expressed as mean \pm SEM, $n=3$ replicate.

$\mathrm{M}=$ methanol, $\mathrm{E}=$ extract, $\mathrm{M}=$ Maerua, $\mathrm{C}=$ crassifolia . 
The preliminary phytochemical screening of the methanol leaf extract showed the presence of flavonoids, alkaloids, tannins, saponins. Plant secondary constituents show different biochemical and pharmacological actions in animals and bacteria when ingested (Trease and Evans, 1989). Alkaloids, tannins and flavonoids have shown to be responsible for the antibacterial and antioxidant activities of different medicinal plants (Gandhare et al., 2010; Nwaogu et al., 2008; Nweze et al., 2004). Thus, the observed antibacterial and antioxidant effects of the leaf extract may be due to the presence of the secondary metabolites. Medicinal plants are essential source of potentially structures for the development of new agents. These observations have helped in identifying the active principle responsible for such activities in developing new drugs for therapeutic use in humans.

The demonstration of activity against test organisms indicates scientific reasons for the local use of this potential medicinally important plant in the treatment of different ailments. The fact that the leaf extract was active against the organisms tested (gram-negative and gram-positive) may suggest a broad spectrum of activity. The observed effect is very important because of the possibility of producing therapeutic agents that will be against drug-resistant organisms. The low minimum inhibitory concentration value observed for Salmonella typhi, is a good indication of high activity against this bacterium. This result is outstanding considering the fact that typhoid fever is on the increase, and also becoming recalcitrant to first-line antibiotics treatment of the organism in developing countries. Apart from antimicrobial properties, the plant extract is also exploited for therapeutic purpose to cure other diseases. The methanol leaf extract of Maerua crassifolia was found to exhibit Antimalarial, antidiarrhoeal, analgesic, anti-inflammatory, antipyretic and gastrointestinal activities (Akuodor et al., 2015; Akuodor et al., 2014; Akuodor et al., 2014; Idris Usman et al., 2010). Free radicals have been implicated in a variety of diseases including bacterial infection and neurological diseases (Rafikali and Nair, 2001).

Although there are medications to manage free radical damage and to protect the body against oxidative stress, the drugs available and in use are known to have severe side effects. The need for natural antioxidants to replace the synthesized ones cannot be overemphasised. The leaf extract exhibited strong antioxidant activity. The addition of methanol leaf extract of Maerua crassifolia to the DPPH solution caused a rapid decrease in the optical density at $517 \mathrm{~nm}$, indicating good scavenging activity of the extract. The extract exhibited substantial antioxidant effect in a dose dependent manner similar to ascorbic acid which was used as a control standard antioxidant. The findings of this study supports the traditional application of the leaf extract and suggests that it possess constituents with antimicrobial and antioxidant properties.

\section{CONFLICT OF INTEREST STATEMENT}

We declare that we have no conflict of interest.

\section{ACKNOWLEDGEMENT}

The authors are grateful to the Department of Medicinal Plant and traditional Medicine, National Institute for Pharmaceutical Research and Development (NIPRD), Abuja, Nigeria.

\section{REFERENCES}

Abubakar BA, Aliyu MM, Mikhail SA, Hamisu I, Adebayo'o O. Phytochemical screening and antibacterial activities of Vernonia ambigua, Vernonia blumeoides and Vernonia oocephala (Asteraceae). Natural Drugs, 2009; 3:45-54.

Akuodor GC, Essiet GA, Ajoku GA, Ezeunala MN, Chilaka KC. Antimalarial Potency of the methanol leaf extract of Maerua crassifolia Forssk (Capparaceae). Asian Pacific Journal of Tropical Disease, 2014a; 4(1):35-39.

Akuodor GC, Ibrahim JA, Akpan JL, Okorie AU, Ezeokpo BC. Phytochemical and antidiarrhoeal properties of methanolic leaf extract of Maerua crassifolia Forssk. European Journal of Medicinal Plants, 2014; 4(10): 1223-1231.

Akuodor GC, Essien AD, Akpan JL, Chilaka KC, Uwaezuoke NJI' Ezeokpo BC' Nwadike KI. Anti-nociceptive, antiinflammatory and anti-pyretic effects of methanolic leaf extract of Maerua crassifolia in experimental animal models, Avicenna Journal of Phynomedicine, 2015 ; (In press).

Andrews JM. Determination of minimum inhibitory concentration, 2001; J. Antimicrob. Chemother.,48:5-16.

Awah FM, Uzoegwu PN, Oyugi JO, Rutherford J, Ifeonu P, Yao X, Fowke KR, Eze MO. Free radical scavenging activity and immunomodulatory effect of Stachytarpheta angustiflia leaf extract. Food Chem., 2010; 119: 1409-1416

Gandhare B, Soni N, Dhongade HJ. In vitro antioxidant activity of Bombax ceiba. Int. J. Biomed Res., 2010; 1(2):31-36.

Gupta M, Mazumder UK. In vitro antioxidant and free radical scavenging activities of Galega purpurea, Phcog Mag. 2007; 3:218-224.

Idris-Usman MS, Akuodor GC, Idris HS, Akpan JL, Ugwu TC,

Anyalewechi NA, Osunkwo UA. (2010). Gastrointestinal properties of the ethanolic leaf extract of Maerua crassiflia. African Network for Drugs and Diagnostic Innovation (ANDI), Nairobi, Kenya; PP. 63.

Kumar HNK, Preethi E, Chandana E, Chauhan JB. Phytochemical screening antibacterial activity of Stachytarpheta indica. Int. J. Pharma Sci Res., 2012; 3: 1684-1687.

Lata H, Ahuja GK. Role of free radicals in health and disease. Indian Journal of Physiology and Allied Sciences, 2003; 57: 124-126.

Mahesh B, Satish S. Antimicrobial activity of some important medicinal plant against plant and human. World Journal of Agricultural sciences, 2008; 4: (S):839-843.

Mbaveng AT, Ngameni B, Kuete V, Simbo IK, Ambasa P, Ros R, Bezabi M, Etoa FX, Ngadjuri BT, Abagaz BM, Mayer JJM, Lall N, Deng VT. Antimicrobial activity of crude extracts of and five flavonoids from the twigs of Dorstenia barteri(Moraceae). J. Ethnopharmacol., 2008; 116: 483-489.

Mothana RAA, Abdo SAA, Hasson S, Althawas FMN, Alaghbari SAZ, Lindequist U. Antimicrobial, antioxidant and cytotoxic activities and phytochemical screening of some Yemeni medicinal plants. J. Evid Based Complement alternat Med., 2010; 7 (3): 232-330.

Mukherjee PR. 2006. Quality control of herbal Drugs, an Approach to Evaluation of Botanicals. $13^{\text {th }}$ Edn. New Delhi: Business Horizones Publisher. p. 419-459.

NCCLS. Performance standard for antimicrobial disc susceptibility test. Approved standard NCCLS Documents M2-A5, National Committee for Chemical Laboratory Standards, 1993; Pennsylvania, USA.

Nwaogu LA, Alisi CS, Igwe CU, Ujowundu CO. A comperative study of the antimicrobial properties of the ethanolic extracts of 
Landolphia owariensis leaf and root. Afr. J. Biotechnol. 2008; 7 (4): 368372.

Nweze EL, Okafor JI, Njoku O. Antimicrobial activities of methanolic extracts of Trema guinensis (Schumm and Thorn) and Morinda lucida Benth used in Nigeria. J. Bio. Res., 2004; 2:39-46.

Panda S, Kar A. Annona squamosa seed extract in the regulation of hyperthyroidism and lipi-peroxidation in mice: possible involvement of quer cetin. Phytomedicine, 2007; 14: 799-805.

Parekh J, Karathia N, Chanda S. Evaluation of antibacterial activity and phytochemica analysis of Bauhinia variegates L. Bark. Afr. J. Biomed Res., 2006; 9 (1):53-56.

Rafikali, A.M., and Nair, M.G. Mosquitocidal, nematicidal, and antifungal compounds from Apium graveolens L. seeds. Journal of Agriculture and food Chemistry,2001; 49: 142-145.
Rahman MA, Mossa JS, Al-Said MS, Al-Yahya MA. Medicinal plant diversity in the flora of Sauidi Arabia 1: A report on seven plant families. Fitoterapia, 2004; 75: 145-161.

Trease GE, Evans WC. Test book of Pharmacognosy. $13^{\text {th }}$ Edn. London: balliere Tindal, 1989; p. 176-1

\section{How to cite this article:}

Chilaka KC, Akuodor GC, Akpan JL, Ogiji ED, Eze CO, Ezeokpo BC. Antibacterial and antioxidant activities of methanolic leaf extract of Maerua crassifolia. J App Pharm Sci, 2015; 5 (10): 147150 . 